DOI: https://doi.org/10.47405/mjssh.v6i10.1114

\begin{tabular}{|c|c|}
\hline (7) & Malaysian Journal of Social Sciences and Humanities (MJSSH) \\
\hline $\begin{array}{l}\text { Malaysian Journa of } \\
\text { calss }\end{array}$ & Volume 6, Issue 10, October 2021 \\
\hline (MJ-SSH) & e-ISSN : 2504-8562 \\
\hline & $\begin{array}{l}\text { Journal home page: } \\
\text { www.msocialsciences.com }\end{array}$ \\
\hline
\end{tabular}

\title{
Hubungan Antara Komuniti Pembelajaran Profesional dan Komitmen Guru di Sekolah Menengah Kebangsaan di Malaysia
}

\author{
Azura Pun', Mahaliza Mansor' ${ }^{1}$ \\ ${ }_{1}^{1}$ Fakulti Pengurusan dan Ekonomi, Universiti Pendidikan Sultan Idris (UPSI), Perak, Malaysia \\ Correspondence: Azura Pun (azuraailinnizzuan@gmail.com)
}

\begin{abstract}
Abstrak
Kajian ini bertujuan mengenal pasti hubungan di antara komuniti pembelajaran profesional dengan komitmen guru di sekolah menengah kebangsaan di Malaysia. Kajian ini menggunakan pendekatan kuantitatif melalui kaedah tinjauan yang melibatkan seramai 702 orang guru sekolah menengah harian di Malaysia. Kaedah persampelan berstrata tidak berkadaran telah digunakan dalam pemilihan sampel. Data dianalisis dengan menggunakan perisian SPSS versi 23. Hasil dapatan menunjukkan bahawa komuniti pembelajaran profesional mempunyai hubungan yang positif tetapi sederhana terhadap komitmen guru dengan nilai pekali korelasi $\mathrm{r}=0.432$ dan analisis regresi $(\mathrm{R}=0.432)$. Kajian ini boleh menjadi rujukan kepada Kementerian Pendidikan Malaysia, Institut Aminuddin Baki dan Institut Pendidikan Guru untuk merangka program pembangunan profesional yang berkesan untuk pemimpin sekolah dan guru. Kesimpulannya, pelaksanaan komuniti pembelajaran profesional yang berkesan membawa kesan positif dan dapat meningkatkan komitmen guru sekolah menengah kebangsaan di Malaysia.Kajian tinjauan ini bertujuan untuk mengenal pasti sama ada terdapat hubungan antara motivasi.
\end{abstract}

Kata kunci: komuniti pembelajaran profesional, komitmen guru, Sekolah Menengah Kebangsaan

\section{The Relationship Between the Profesional Learning Community and Teacher Commitment in National School Secondary in Malaysia}

\begin{abstract}
This study aims to identify the relationship between the Professional Learning Community and Teacher Commitment in Malaysia national secondary schools. A quantitative survey method was employed which involved 702 teachers. The disproportionate stratified sampling method was used in sample selection. The data was analysed using SPSS version 23. The results showed that the professional learning community had a positive but moderate relationship to teacher commitment with a correlation coefficient value of $r=0.432$ and regression analysis $(R=0.432)$. The study provides insights for the Ministry of Education Malaysia, Institut Aminuddin Baki and Teacher Education Institute in developing effective professional development programmes for school principals and teachers. In conclusion, the implementation of an effective professional learning community has a positive impact and can increase the commitment among national secondary school teachers in Malaysia.
\end{abstract}

Keywords: professional learning community, teacher commitment, National Secondary Schools 


\section{Pengenalan}

Dalam menghadapi era globalisasi, peranan pendidikan dalam memacu pembangunan negara dalam bidang politik, ekonomi mahupun sosial dilihat amat penting (Samruhaizad \& Azahan, 2017) kerana modal utama untuk mengatasi cabaran era pendidikan 4.0 dan dunia teknologi adalah melalui ilmu pengetahuan (Adam, Muhammad Hilmi \& Taufiq, 2019). Sehubungan itu, kajian menyeluruh telah dilakukan terhadap sistem pendidikan negara oleh Kementerian Pendidikan melalui Pelan Pembangunan Pendidikan Malaysia (PPPM, 2012). Pelan Pembangunan Pendidikan Malaysia yang dibangunkan ini melakarkan visi sistem pendidikan dan murid bagi memenuhi keperluan negara pada masa hadapan selain mencadangkan 11 anjakan strategik dan operasi yang perlu dilaksanakan oleh Kementerian Pendidikan bagi mencapai visi yang dihasratkan (PPPM, 2012).

Bagi meningkatkan prestasi sekolah dan pencapaian murid, seluruh warga sekolah perlu sentiasa bekerjasama untuk membuat penambahbaikan kualiti pengajaran dan pembelajaran. Sehubungan itu, komuniti pembelajaran profesional telah dikenal pasti sebagai mekanisme dan kerjasama profesional penting untuk meningkatkan tahap pembelajaran murid (Chong, Muhammad Faizal \& Zuraidah, 2018). Kerjasama profesional dibuktikan melalui komuniti pembelajaran profesional apabila warga sekolah khususnya guru-guru dan barisan pentadbir berkongsi maklumat, memberi idea serta bermuafakat untuk mencapai matlamat organisasi (Leonard \& Leonard, 2001). Malahan, menurut Ho, Lee dan Teng (2016), strategi untuk memperkasakan pencapaian sekolah adalah dengan memupuk dan membudayakan pembelajaran profesional yang mana para guru bukan sahaja meningkatkan amalan terbaik dalam pengajaran tetapi juga mewujudkan komuniti pembelajaran. Implikasinya, amalan berkolaboratif akan menjadi rutin para guru untuk menjadi guru berkesan dan seterusnya melahirkan murid yang berjaya.

Seterusnya, menurut Alsaeedi dan Male (2013), dalam persekitaran global yang penuh dengan persaingan pada hari ini, banyak organisasi menghadapi pelbagai masalah dan cabaran untuk mencapai matlamat. Sehubungan itu, bagi memastikan organisasi dapat bertahan dan mampu bersaing dalam persekitaran yang dinamik, organisasi amat memerlukan sumber manusia yang aktif dan mempunyai komitmen yang tinggi agar organisasi dapat bertahan lama (Sadia, 2011). Maka, dalam bidang pendidikan, guru merupakan sumber manusia yang sangat penting untuk menjayakan misi dan visi pendidikan negara. Oleh itu, komitmen guru merupakan faktor utama dalam menjayakan pendidikan dan kecemerlangan murid serta sekolah (Luxmi \& Yadav, 2011).

Kesimpulannya, komuniti pembelajaran profesional dilihat sebagai unsur penting untuk meningkatkan komitmen guru dan seterusnya mentransformasikan sesebuah sekolah dalam usaha meningkatkan pencapaian murid dan sekolah. Menurut Pancucci (2008), komuniti pembelajaran profesional bukan sahaja berupaya meningkatkan komitmen guru, malahan telah menambah baik keperibadian guru, kemahiran interpersonal dan keupayaan mengurus. selain itu, komuniti pembelajaran profesional juga didapati berjaya meningkatkan dan menambah baik komitmen guru terhadap murid (Lee, Zhang \& Yin, 2011; Jia \& Sun, 2019). Oleh itu, kajian ini bertujuan untuk mengenal pasti hubungan komuniti pembelajaran profesional dan komitmen guru berdasarkan latar belakang sekolah menengah kebangsaan di Malaysia.

\section{Pernyataan Masalah}

Dalam organisasi pendidikan seperti sekolah, komitmen guru memainkan peranan yang amat penting kerana melibatkan isu murid, sekolah dan profesion guru (Nordin, Darmawan \& Keeves, 2010). Guru yang mempunyai komitmen yang tinggi merupakan guru yang bertanggungjawab (Relly, 2015; Shafiq \& Rana, 2016). Menurut Voet, Kuipers dan Greoneveld (2016), komitmen guru merupakan kunci utama kejayaan perubahan yang dilakukan di sekolah. Walaupun guru-guru di Malaysia menerima latihan perguruan yang sama, guru-guru juga tidak terkecuali daripada mempunyai masalah dalam organisasi sekolah (Intan Salina \& Jamalullail, 2017). Namun demikian, banyak kajian tempatan menunjukkan bahawa komitmen guru di Malaysia berada pada tahap yang rendah (Seravanan \& Shahizan, 2020; Ling \& Mohammed Ibrahim, 2013) dan tahap sederhana sahaja (Kaushalya \& Mohd 
Faiz, 2020; Lily \& Muhamad Suhaimi, 2020; Sheeila \& Mohamed Yusoff, 2018; Zuraimiy, Azizi \& Mohd Nor, 2016; Jamalullail et al., 2014). Oleh itu, bagaimana pengetua sebagai pemimpin sekolah dapat meningkatkan komitmen guru merupakan satu persoalan yang kritikal.

Sehubungan itu, kajian yang dilaksanakan oleh Tai dan Omar (2019), Omar, Tai, Khalip dan Ghouri (2019), Zuraidah (2016), Fullan (2001), McLaughlin dan Talbert (2001) serta Senge, McCabe, Lucas, Smith, Dulton dan Kleiner (2000) mendapati bahawa komuniti pembelajaran profesional merupakan amalan penambahbaikan sekolah menerusi aktiviti pembelajaran dan penjanaan pengetahuan secara kolaboratif dalam kalangan guru yang dapat meningkatkan komitmen guru. Kajian turut menunjukkan komuniti pembelajaran profesional merupakan strategi utama yang boleh diaplikasikan oleh pengetua untuk meningkatkan komitmen guru bagi meningkatkan prestasi sekolah (Hord, 2009; Zuraidah \& Rahimah, 2007; Dufour, Eaker \& Many, 2006; Charles \& Ellen, 2001). Ini disebabkan komuniti pembelajaran profesional dapat memberikan dorongan terhadap pembangunan profesional guru dan pembelajaran murid yang seterusnya menyumbang ke arah reformasi dan kemajuan sekolah (Harris \& Jones, 2010). Pelaksanaan kajian yang meneliti hubungan antara dua pemboleh ubah ini merupakan satu inisiatif yang bermakna dalam proses memacu hala tuju negara dalam bidang pendidikan dan mentransformasikan sistem pendidikan negara kita ke arah yang cemerlang.

\section{Kerangka Konseptual}

Kerangka konseptual dalam Rajah 1 memperlihatkan hubungan di antara dua pemboleh ubah iaitu komuniti pembelajaran profesional dan komitmen guru. Pemboleh ubah komuniti pembelajaran profesional adalah berdasarkan teori organisasi pembelajaran oleh Senge (1990), model komuniti pembelajaran profesional oleh Hord (1997) dan model komuniti pembelajaran profesional oleh Tai, Omar dan Ghouri (2018). Lapan dimensi dalam kerangka adalah berdasarkan model komuniti pembelajaran profesional oleh Tai, Omar dan Ghouri (2018). Lapan dimensi tersebut ialah norma dan visi bersama, komitmen dan sokongan pengetua, sokongan berstruktur, persefahaman dan kepercayaan rakan sekerja, pembelajaran kolaboratif, dialog reflektif, inkuiri reflektif dan sokongan luar. Pemboleh ubah komitmen guru pula adalah berdasarkan teori Side-Bet Becker (1960) dan tiga dimensi dalam kerangka adalah berdasarkan model komitmen guru oleh Teh (2019) iaitu komitmen pada murid, komitmen pada sekolah dan komitmen pada profesion.

\section{Rajah 1: Kerangka Konseptual Kajian}

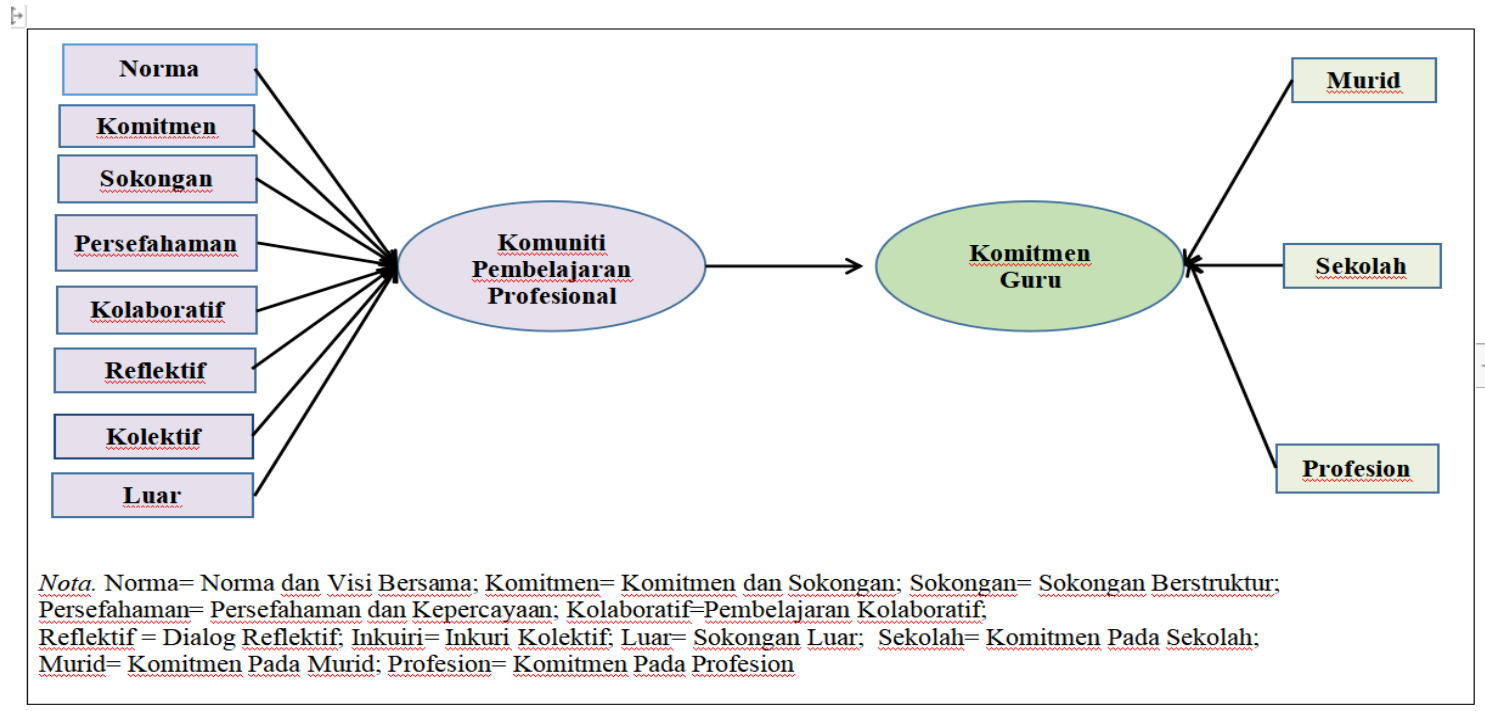




\section{Sorotan Literatur}

Menurut Dufour (2004), pendekatan menggunakan komuniti pembelajaran profesional didapati memberi kesan yang positif terhadap pembangunan profesionalisme guru secara menyeluruh. Perkongsian ilmu dan usaha dalam pengajaran dan pembelajaran yang dilakukan oleh guru melalui komuniti pembelajaran profesional dapat meningkatkan komitmen guru (Wieczorek \& Lear, 2018; Martin, 2012; Zuraidah, 2009). Malahan, komuniti pembelajaran profesional juga adalah rangkaian formal yang menjadi platform untuk meningkatkan kolaboratif guru dan amalan penambahbaikan sekolah (Carpenter, 2018).

Selain itu, guru-guru juga menjadi lebih komited terhadap sekolah apabila mereka terlibat dalam pembelajaran kolektif melalui komuniti pembelajaran profesional (Zhang \& Sun, 2019). Para guru akan lebih memberi komitmen pada sekolah apabila mereka berasa dibantu dan diberi perhatian oleh guru-guru lain. Interaksi dengan rakan sejawat juga akan membantu mengatasi perasaan terasing dan menimbulkan perasaan kebersamaan (Cammelia \& Jati, 2017). Malahan, kolaboratif melalui komuniti pembelajaran profesional membantu para guru merasai ganjaran daipada pengajaran dan pembelajaran yang dijalankan. Oleh itu, guru akan menyempurnakan setiap tugasan dengan komitmen yang tinggi.

Malahan, pengetua dapat meningkatkan komitmen guru melalui pelaksanaan komuniti pembelajaran profesional di sekolah (Hausman \& Goldring, 2001). Menurut Jia dan Yuantao (2019), komitmen guru meningkat apabila pemimpin sekolah dan struktur organisasi memberikan sokongan pada aktiviti kolaboratif guru. Malahan, dengan berkongsi tanggungjawab bersama dalam komuniti pembelajaran profesional, komitmen guru dapat ditingkatkan (Jia \& Yuantao, 2019).

Walaupun banyak kajian di luar negara yang menunjukkan komuniti pembelajaran profesional mempunyai hubungan yang signifikan dan positif dengan komitmen guru, namun menurut Khairul Anuar, Walsh, Mallaburn dan Brundett (2017), kajian yang mengaitkan hubungan kedua-dua pemboleh ubah ini masih kurang dijalankan di Malaysia. Sehubungan itu, kajian tentang hubungan komuniti pembelajaran profesional dengan komitmen guru seterusnya dibincangkan berdasarkan lapan dimensi dalam model komuniti pembelajaran profesional oleh Tai, Omar dan Ghouri (2018) iaitu i) norma dan visi bersama, ii) komitmen dan sokongan pengetua, iii) sokongan berstruktur, iv) persefahaman dan kepercayaan rakan sekerja, v) pembelajaran kolaboratif, vi) dialog reflektif, vii) inkuiri kolektif, dan viii) sokongan luar.

Menurut Tai dan Omar (2019), norma dan visi bersama merujuk pada sejauh mana warga sekolah berkongsi visi tentang pembelajaran, pedagogi, peningkatan dan keberkesanan sekolah serta sokongan terhadap norma tingkah laku bagi mencapai visi pembelajaran yang dikehendaki. Malahan, Dufour dan Eaker (1998) menjelaskan bahawa asas komuniti pembelajaran profesional ialah berkongsi visi untuk pembelajaran murid dan melalui perkongsian ini, komitmen kolektif dalam kalangan komuniti sekolah akan terbentuk. Selain itu, menurut Chong, Muhammad Faizal dan Zuraidah (2016), amalan berkongsi visi beerti berkongsi gambaran tentang masa hadapan dan seterusnya mewujudkan komitmen dalam kalangan warga sekolah untuk membentuk satu pasukan demi mencapai matlamat bersama.

Dimensi sokongan dan komitmen pengetua mempunyai hubungan dengan komitmen guru melalui maklum balas konstruktif penyeliaan pengajaran guru. Menurut Ling dan Norasmah (2018), komitmen pengetua dalam membuat penyeliaan yang berkesan dapat meningkatkan motivasi guru untuk lebih bersedia mengajar dan seterusnya meningkatkan komitmen guru dalam meningkatkan kualiti pengajaran dan pembelajaran. Hal ini demikian kerana penyeliaan bukan sahaja membantu mengatasi masalah pengajaran, malah membantu dalam pengurusan bahan bantu mengajar dan penggunaan kaedah pengajaran yang sesuai (Tay, Yap \& Wong, 2016). Malahan, sokongan dan komitmen pengetua dalam memperuntukkan masa mencukupi kepada guru untuk menyelesaikan tugas dan menjalankan aktiviti kolaboratif dalam komuniti pembelajaran profesional akan menjadikan guru lebih efektif serta memberi komitmen dalam pengajaran (Arzizul \& Dayang Norizah, 2018; Chong et al., 2016; Dima Mazlina, 2016). 
Dimensi sokongan berstruktur melibatkan kemudahan, sumber, pengurusan masa, dana dan ruang (Tai \& Omar, 2019). Kemudahan sekolah yang baik memudahkan guru menjalankan aktiviti pengajaran dan pembelajaran dalam komuniti pembelajaran profesional di sekolah dengan selesa dan mengekalkan komitmen mereka terhadap sekolah (Rohani, Dayang Norizah \& Colonius, 2019). Begitu juga dengan peruntukan kewangan dan dana yang mencukupi dapat digunakan untuk menyelenggara program pembangunan profesionalisme dan aktiviti sekolah (Roslizam, Jamilah \& Yusof, 2018; Cornier, 2009; Alias, Nik Mohd Rahimi \& Ruhizan, 2001). Oleh itu, guru lebih yakin, bermotivasi dan komited untuk menjalankan aktiviti komuniti pembelajaran profesional kerana mendapat sokongan dari segi peruntukan kewangan.

Seterusnya, dimensi persefahaman dan kepercayaan rakan sejawat menjelaskan sejauh mana komuniti sekolah membina persefahaman, kepercayaan, kesedaran dan keprihatinan dalam menyelesaikan masalah, mengambil keputusan dan menggalakkan perubahan dalam proses mencapai matlamat pembelajaran di sekolah (Tai \& Omar, 2019). Hubungan baik antara rakan sejawat dalam Komuniti pembelajaran Profesional sebenarnya dapat meningkatkan komitmen guru untuk berkongsi idea demi kebaikan murid dan sekolah (Trust \& Horrock, 2016). Persefahaman dan kepercayaan rakan sejawat dapat mengelak guru daripada mengasingkan diri dan bekerja secara bersendirian sebaliknya mengamalkan budaya perkongsian pengalaman dan bahan pengajaran dengan rakan sejawatan (Aziah, Loh \& Abdul Ghani, 2015; Kamaruddin, Rosnah, Fanny Kho \& Siti Hajar, 2019).

Dimensi pembelajaran kolaboratif meningkatkan komitmen guru secara berterusan dalam membuat analisis data ke arah peningkatan prestasi murid (Roslizam et al., 2018). Berdasarkan analisis data yang dijalankan, maklumat tentang masalah pembelajaran murid dapat dikesan dan intervensi yang tepat dapat dilakukan untuk membantu meningkatkan pencapaian murid (Killian \& Bellamy, 2000). Apabila guru mengetahui punca masalah pembelajaran murid melalui analisis data, maka guru lebih yakin untuk memberi komitmen dalam membantu pencapaian murid dan kemajuan sekolah. Malahan menurut Bantwini (2018), pembelajaran kolaboratif membolehkan guru berkongsi dan bertukar bahan pengajaran. Pengkongsian maklumat dan pengetahuan dalam kalangan guru bukan sahaja mengukuhkan amalan pengajaran guru tetapi turut meningkatkan komitmen guru dalam memberikan pengajaran terbaik kepada murid (Mumtaz, 2008).

Seterusnya, dimensi dialog reflektif bukan sahaja dapat memantapkan komuniti pembelajaran profesional tetapi juga menonjolkan komitmen guru dalam meningkatkan pembangunan profesionalisme. Melalui dialog reflektif, guru terlibat secara aktif untuk mendapat pemahaman baharu tentang amalan pengajaran terbaik dengan mengambil kira pandangan rakan sejawat (Selcuk \& Alyson, 2018; Sujirah, 2011). Malahan, perkongsian ilmu dan perbincangan dalam dialog reflektif, memberi idea kepada guru untuk membuat pengubahsuaian dalam teknik pengajaran supaya sesuai dengan perkembangan pendidikan semasa di samping dapat meningkatkan keberkesanan pembelajaran dan pencapaian murid (Dima Mazlina, 2016; Downey et al., 2004). Oleh itu, amalan sebegini akan menyebabkan guru-guru terus komited untuk menyuburkan pembelajaran mereka (Zuraidah Abdullah, 2009).

Dimensi inkuiri kolektif pula membolehkan guru mencari pengetahuan dan kemahiran untuk diaplikasi dalam aktiviti pengajaran dan pembelajaran. Inkuiri kolektif menyebabkan guru cenderung untuk berkongsi ilmu dalam komuniti sekolah. Perkongsian ilmu akan membawa kepada aktiviti susulan seperti perjumpaan mingguan yang dapat memupuk semangat kerjasama dan meningkatkan komitmen guru untuk membuat penambaihbaikan secara berterusan dalam pengajaran dan pembelajaran (Dima Mazlina, 2016; Siti Nafsiah, Zuraidah \& Abdul Jalil, 2020). Malahan, inkuiri kolektif membolehkan guru-guru memberi komitmen terhadap aktiviti pengajaran dan pembelajaran yang berkaitan pencapaian murid melalui maklumat yang diterima berdasarkan perbincangan jujur dan terbuka yang dilakukan dalam komuniti pembelajaran profesional (Siti Noor, 2018).

Dimensi sokongan luar juga dilihat mempunyai kesan terhadap peningkatan komitmen guru melalui usaha kolaboratif dengan pihak yang berkepentingan seperti keluarga, masyarakat, Pejabat Pendidikan Daerah dan Jabatan Pendidikan Negeri dalam usaha untuk mencapai visi dan misi pembelajaran sekolah (Tai \& Omar, 2019). Kesediaan ibu bapa untuk melibatkan diri dalam perkara berkaitan 
murid menjadi motivasi kepada guru untuk terus meningkatkan komitmen demi pencapaian murid dan kemajuan sekolah (Arzizul \& Dayang, 2018). Begitu juga dengan peranan komuniti setempat seperti menawarkan bantuan kewangan bagi membolehkan aktiviti pembelajaran melalui komuniti pembelajaran profesional dapat dijalankan dengan lancar (Halimah, 2017; Jia \& Sun, 2016). Kerjasama semua pihak dalam program pembangunan sekolah dapat membantu guru meningkatkan komitmen terhadap pencapaian murid secara berterusan (Halimah, Eow \& Chuah, 2014a).

\section{Metod Kajian}

Populasi kajian ini berfokus pada guru-guru sekolah menengah kebangsaan di Malaysia. Kajian ini menggunakan pendekatan kuantitatif melalui kaedah tinjauan. Kaedah tinjauan dipilih kerana kaedah ini membolehkan penyelidik menganalisis maklumat berdasarkan soal selidik yang diedarkan. Data untuk kajian ini dianalisis menggunakan perisian SPSS versi 2.3.

\section{Kaedah Persampelan Dan Kutipan Data}

Kaedah persampelan yang digunakan dalam kajian ini ialah kaedah persampelan berstrata tidak berkadaran. Kaedah persampelan bermaksud saiz sampel dalam setiap unit tidak berkadaran dengan saiz unit (Yogesh, 2006). Oleh itu, persampelan berstrata tidak berkadaran yang digunakan dalam kajian ini meletakkan jumlah sampel yang sama rata dalam setiap unit seperti yang dicadangkan oleh Daniel (2011). Berdasarkan jadual penentuan sampel oleh Cohen (2001) bilangan sampel yang diperlukan ialah sebanyak 659 orang responden daripada jumlah populasi guru sekolah menengah kebangsaan iaitu 154,021 orang (KPM, 2019). Bagi mendapatkan 659 responden, sebanyak 11 orang guru perlu dipilih secara rawak dari 5 buah sekolah yang melibatkan 13 buah negeri dan 3 wilayah persekutuan $(11$ × 5 x $16=880)$. Sejumlah 880 soal selidik diedarkan dan pulangan yang diperoleh ialah sebanyak $744(84.54 \%)$ seperti dalam Jadual 1. Sampel yang lebih besar dikutip berbanding jumlah yang dicadangkan adalah untuk mengelakkan beberapa masalah seperti soal selidik tidak dipulangkan, tidak dijawab dan tidak lengkap.

Jadual 1: Kutipan Data

\begin{tabular}{lc}
\hline Butiran & Jumlah \\
\hline Jumlah pengeposan soal selidik & 880 \\
Soal selidik tidak dikembalikan & 136 \\
Penerimaan & 744 \\
Soal selidik dikembalikan tanpa dijawab & 22 \\
Soal selidik dijawab tidak lengkap & 18 \\
Soal selidik boleh guna & 702 \\
\hline
\end{tabular}

Penghantaran soal selidik ke sekolah-sekolah adalah menggunakan pos biasa bagi menjimatkan kos. Setiap sampul mengandungi dokumen i) surat kebenaran menjalankan penyelidikan pendidikan daripada Bahagian Perancangan dan Penyelidikan Dasar Pendidikan (BPPDP); ii) surat kebenaran daripada Jabatan Pelajaran Negeri / Wilayah Persekutuan; iii) surat makluman kepada pengetua tentang jumlah responden yang dipilih dan tarikh soal selidik perlu dikembalikan kepada penyelidik; iv) 11 set instrumen yang akan dijawab oleh guru-guru; dan v) sampul surat bersetem sendiri berserta alamat penyelidik untuk memudahkan pihak sekolah mengembalikan soal selidik.

\section{Instrumen Kajian}

Pemboleh ubah komuniti pembelajaran profesional diukur menggunakan item daripada skala komuniti pembelajaran profesional yang dibangunkan oleh Tai, Omar dan Ghouri (2018) yang mengandungi lapan dimensi dan 44 item. Pemboleh ubah komitmen guru dalam kajian ini pula diukur menggunakan skala Komitmen Guru yang telah digunakan oleh Teh (2019) yang mengandungi tiga dimensi dan sembilan. 


\section{Hasil Kajian}

Bagi mengukur hubungan komuniti pembelajaran profesional dan komitmen guru, dua kaedah analisis digunakan iatu analisis korelasi Pearson dan analisis regresi. Aras kekuatan hubungan di antara komuniti pembelajaran profesional dan komitmen guru dikira berpandukan skala kekuatan hubungan oleh Cohen, Manion dan Marrison (2011) seperti yang ditunjukkan dalam Jadual 2.

Jadual 2: Aras Kekuatan Nilai Pekali Korelasi

\begin{tabular}{lc}
\hline \multicolumn{1}{c}{ Saiz Pekali Korelasi $(\mathbf{r})$} & Kekuatan Korelasi \\
\hline \pm .81 hingga 1.00 & Sangat Kuat \\
\pm .51 hingga .80 & Kuat \\
\pm .31 hingga .50 & Sederhana \\
\pm .21 hingga .30 & Lemah \\
\pm .01 hingga .20 & Sangat Lemah \\
\hline
\end{tabular}

\section{Analisis Korelasi Pearson}

Berdasarkan Jadual 3 dapat dilihat wujudnya korelasi yang sederhana di antara komuniti pembelajaran profesional dan komitmen guru dengan nilai signifikan $p=0.05$ dan nilai pekali, $r=0.423$. Hubungan yang sederhana di antara kedua-dua pemboleh ubah tersebut menunjukkan bahawa semakin baik amalan komuniti pembelajaran semakin tinggi komitmen di sekolah menengah kebangsaan di Malaysia.

Jadual 3: Analisis Korelasi Komuniti Pembelajaran Profesional Dengan Komitmen Guru

\begin{tabular}{lcc}
\hline & $\begin{array}{c}\text { Komuniti Pembelajaran } \\
\text { Profesional }\end{array}$ & Komitmen Guru \\
\hline Pearson Correlation & 1 & $.432^{* *}$ \\
Sig. (1-tailed) & 702 & .000 \\
$\mathrm{~N}$ & $.432^{* * *}$ & 702 \\
Pearson Correlation & .000 & 1 \\
Sig. (1-tailed) & 702 & 702 \\
\hline $\mathrm{N}$ & ${ }^{* *}$. Correlation is significant at the 0.01 level (1-tailed).
\end{tabular}

\section{Analisis Regresi}

Regresi merupakan kaedah analisis untuk menyiasat hubungan antara pemboleh ubah yang bersifat kuantitatif (Ramlee, Jamal \& Marinah, 2020). Dalam kajian ini, Jadual 4 menunjukkan $R=0.432$ yang menterjemahkan terdapatnya hubungan yang sederhana di antara komuniti pembelajaran profesional dengan komitmen guru di sekolah menengah kebangsaan di Malaysia.

Jadual 4: Analisis Regresi

\begin{tabular}{lllll}
\hline Model & R & R Square & $\begin{array}{l}\text { Adjusted R } \\
\text { Square }\end{array}$ & $\begin{array}{l}\text { Std. Error of the } \\
\text { Estimate }\end{array}$ \\
\hline 1 & $.432^{\mathrm{a}}$ & .186 & .185 & .38146 \\
\hline
\end{tabular}

a. Predictors: (Constant), komuniti pembelajaran profesional 


\section{Perbincangan Kajian}

Berdasarkan konteks kajian di sekolah menengah kebangsaan di Malaysia, komuniti pembelajaran profesional dikenal pasti sebagai satu alternatif yang dilihat dapat meningkatkan komitmen dalam kalangan guru. Norma dan visi bersama, komitmen dan sokongan pengetua sekolah, sokongan berstruktur, persefahaman dan kepercayaan rakan sekerja, pembelajaran kolaboratif, dialog reflektif, inkuiri kolektif dan sokongan luar merupakan lapan faktor penting komuniti pembelajaran profesional untuk meningkatkan komitmen guru terhadap murid, sekolah dan profesion. komitmen guru yang tinggi akan menjurus kepada pencapaian cemerlang murid dan seterusnya meningkatkan prestasi sekolah. Oleh itu, sumbangan komuniti pembelajaran profesional dalam meningkatkan komitmen guru harus diberi perhatian oleh pemimpin sekolah ke arah mewujudkan sistem pendidikan yang berkualiti dan berdaya saing.

Hasil kajian ini juga mendapati bahawa komuniti pembelajaran profesional mempunyai hubungan yang sederhana dengan komitmen guru. Ini menunjukkan bahawa komuniti pembelajaran profesional mempunyai pengaruh terhadap komitmen guru. Sehubungan itu, komuniti pembelajaran profesional merupakan amalan terbaik yang dapat menyatukan guru-guru bagi meningkatkan kualiti diri sebagai seorang guru (Roslizam et al., 2018). Malahan, melalui komuniti pembelajaran profesional, guru lebih yakin dengan kebolehan diri dan berupaya memberikan komitmen yang padu demi kejayaan murid, kecemerlangan sekolah serta pemantapan profesion. Komitmen dan semangat baharu akan wujud dalam kalangan guru jika mereka diberikan peluang untuk memberi pandangan serta terlibat dalam aktiviti kolaboratif dan dialog profesional melalui komuniti Pembelajaran Profesional (Slick, 2008).

Dapatan kajian ini juga konsisten dengan dapatan kajian oleh Hord (1997) bahawa guru menjadi lebih komited terhadap sekolah apabila mereka terlibat dalam komuniti pembelajaran profesional. Guru yang terlibat dalam komuniti pembelajaran profesional didapati lebih komited terhadap murid (Fransson \& Frelin, 2016; Hausman \& Goldring, 2001). Malahan kajian Lee, Zhang dan Yin (2011) serta Chan et al. (2008) menunjukkan bahawa aktiviti komuniti pembelajaran profesional seperti dialog reflektif menjadikan guru lebih komited untuk membantu meningkatkan prestasi pelajar.

Penglibatan dalam aktiviti komuniti pembelajaran profesional juga dapat mewujudkan suasana bekerja yang baik, membina hubungan akrab dalam kalangan guru dan seterusnya mendorong guru lebih komited terhadap profesion mereka (Markku, Liisa, Pekka \& Auli, 2018). Komuniti pembelajaran profesional bukan sahaja mempunyai kesan terhadap komitmen guru tetapi turut memberi implikasi bahawa pemimpin sekolah seperti pengetua perlu membangun dan membudayakan komuniti pembelajaran profesional bagi meningkatkan komitmen guru (Jia \& Yuantao, 2019).

Sehubungan itu, penyelidikan akan datang mungkin boleh memfokuskan kategori sekolah menengah lain selain daripada sekolah menengah kebangsaan seperti Maktab Rendah Sains Mara, Sekolah Berasrama Penuh, Sekolah Menengah Agama, Kolej Teknik dan Vokasional dan sekolah menengah swasta untuk mendapatkan data yang lebih menyeluruh tentang pengaruh serta kesan komuniti pembelajaran profesional terhadap komitmen guru di Malaysia.

\section{Kesimpulan}

Komuniti pembelajaran profesional memainkan peranan yang kritikal dalam meningkatkan komitmen guru. Sehubungan itu, guru sebagai individu yang paling hampir dengan murid dan paling memahami serta mengetahui keperluan murid dalam proses pembelajaran harus melibatkan diri secara aktif dalam komuniti pembelajaran profesional. Guru dapat berkongsi pengalaman dan pengetahuan secara kolaboratif dalam komuniti pembelajaran profesional serta mencipta pengetahuan baharu yang dapat memanfaatkan pembelajaran murid. Usaha membudayakan dan mengekalkan komuniti pembelajaran profesional merupakan kaedah paling efektif untuk meningkatkan minat dan keberkesanan pembelajaran dalam komuniti sekolah agar dapat menjadi budaya seluruh warga sekolah. 
Pembudayaan komuniti pembelajaran profesional yang berkesan dapat memberi impak kepada komitmen guru yang dapat meningkatkan pembangunan profesionalisme kendiri, kemajuan sekolah dan peningkatan prestasi murid. Pelaksanaan komuniti pembelajaran profesional yang berkesan dapat memberi semangat kepada guru untuk memberikan komitmen padu terhadap matlamat sekolah serta pencapaian pelajar; pembelajaran yang berkesan melalui komuniti pembelajaran profesional dapat meningkatkan keyakinan dan keupayaan guru untuk melaksanakan aktiviti pengajaran dan pembelajaran yang bermakna di bilik darjah. Sehubungan itu, kajian ini dapat membekalkan makluman kepada pihak yang berkenaan seperti Institut Aminuddin Baki (IAB), Institut Pendidikan Guru (IPG) dan Kementerian Pendidikan Malaysia (KPM) yang terlibat dalam merancang dan menjalankan kursus untuk para guru dan pemimpin sekolah di Malaysia. Malahan, kajian ini boleh dijadikan rujukan kepada pihak KPM dan IAB dalam proses mereka bentuk program latihan pembangunan untuk pemimpin sekolah khususnya dalam usaha untuk meningkatkan komitmen guru di sekolah.

\section{Rujukan}

Adam Badhrulhisham, Muhammad Hilmi Mat Johar \& Taufiq A. Rashid. (2019). Mendepani cabaran revolusi industri 4.0 (ir 4.0) dalam konteks mahasiswa: analisis menurut perspektif Islam. Journal of Ilmi, 9, 90-101.

Arzizul Antin \& Dayang Norizah Awang Kiflee. (2018). Pengaruh Beban Tugas dan Motivasi Terhadap Keefisienan Kerja Guru Sekolah Menengah di Sabah. Malaysian Journal of Social Sciences and Humanities (MJSSH), 3(2), 77- 84.

Carpenter, D. (2015). School Culture and Leadership of Professional Learning Communities. International Journal of Education Management, 29(5), 682-69.

Cammellia Othman \& Jati Kasuma (2017). Relationship Of School Climate Dimensions And Teachers' Commitment. International Journal of Advanced and Applied Sciences, 4(3), 94-100.

Chong C. K., Muhammad Faizal A. Ghani \& Zuraidah Abdullah (2016). Amalan Komuniti Pembelajaran Profesional (Kpp) Di Sekolah Berprestasi Tinggi (Sbt) Malaysia: Sebuah Sekolah Jenis Kebangsaan Cina (Sjkc) Di Sarawak. Jurnal Kepimpinan Pendidikan, 3(1).

Chua, Y.P. (2014) Kaedah dan statistik penyelidikan: kaedah penyelidikan. Buku 1. Edisi 3. McgrawHill Education, Shah Alam.

Cohen, L., Manion, L., \& Morrison, K. (2011). Research Methods In Education (7th Ed). London: Routledge, Taylor \& Francis Group.

Donny Susilo (2018). Transformational Leadership; A Style of Motivating Employees. Management and Economics Journal, 2(2).

Dufour, R., Eaker, R., \& Many, T. (2006). Learning by doing: A handbook for professional learning communities at work. Bloomington, IN: Solution Tree.

Fransson, G., \& Frelin, A. (2016). Highly committed teachers: What makes them tick? A study of sustained commitment. Teachers and Teaching, 22(8), 896-912. https://doi.org/10.1080/13540602. 2016.1201469.

James Billy, L. and Taat, M. S. (2020). Budaya Sekolah: Hubungannya dengan Komitmen Guru. Malaysian. Journal of Social Sciences and Humanities (MJSSH), 5(10), 207 - 216. doi: https://doi.org/10.47405/mjssh.v5i10.511.

Jia Zhang \& Yuantao Sun. (2019). Investigating the Effect of Professional Learning Communities on Teacher Commitment in China. Educational Studies. http://doi.org/10.1080/03055698.2019.1651695.

Hausman, C. S., \& Goldring, E. B. (2001). Sustaining teacher commitment: The role of professional communities. Peabody Journal of Education, 76(2), 30-51. https://doi.org/10.1207/ .

Hord, S. M. (1997). Professional learning communities: Communities of continuous inquiry and improvement. Austin, Texas: Southwest Educational Development Laboratory.

Intan Salina Che Sulaiman \& Jamalullail Abdul Wahab. (2017). Pendekatan Kepimpinan Transformasional Menangani Isu Guru Di Sekolah. Simposium Pendidikan di Peribadikan: Perspektif Risalah An-Nur (SPRiN2017).

Kareem, O. A., Kin, T. M., Musa, K. bin, \& Ghouri, A. M. (2019). Professional Learning Communities in Peninsular Malaysia: Comparing Day Secondary School and National 
Religious Secondary School. International Journal of Academic Research in Progressive Education and Development, 8(2), 389-407.

Kaushalya Palanisamy, Mohd Faiz Mohd Yaakob, Mat Rahimi Yusof, Hapini Awang, Mohd Sofian Omar Fauzee \& Hareesol Khun-Inkeeree. (2020). Hubungan Kepimpinan Transformasi Terhadap Kepuasan Kerja Dalam Kalangan Guru di Perlis. Journal of Educational Research and Indigenous Studies, 1(1).

Lee, J. C.-K., Zhang, Z., \& Yin, H. (2011). A Multilevel Analysis of The Impact Of A Professional Learning Community, Faculty Trust In Colleagues And Collective Efficacy On Teacher Commitment To Students. Teaching and Teacher Education, 27(5),820-830. https://doi.org/10.1016/j.tate.2011.01.006.

Ling, C. J., \& Othman, N. (2018). Amalan Penyeliaan dan Hubungannya Dalam Meningkatkan Kualiti Pengajaran Guru. International Journal of Education, Psychology and Counselling, 3(22), 28-48.

Luxmi \& Vibhuti Yadav. (2011). Reciprocation Effect Of Perceived Organizational Support on Organizational Commitment: A Study of School Teachers. Management and Labour Studies. Vol 36, Issue 2, 2011.

Markku Antinluoma, Liisa Ilomaki, Pekka Lahti-Nuuttila, Auli Toom (2018). Schools as Professional Learning Communities. Journal of Education and Learning, 7(5). DOI: $10.5539 / \mathrm{jel} . \mathrm{v} 7 \mathrm{n} 5 \mathrm{p} 76$.

Ramlee Ismail, Jamal@Nordin Yunus \& Marinah Awang. (2020). Analisis Data dan Pelaporan Dalam Penyelidikan Pendidikan. Universiti Pendidikan Sultan Idris.

Rohani Marasan, Dg. Norizah Ag. Kiflee @ Dzulkifli \& Colonius Atang. (2019). Kepimpinan Pengetua Berdasarkan Atribut Semula Jadi dalam Memartabatkan Profesionalisme Keguruan di SMK St Micheal Penampang, Sabah. Malaysian Journal of Social Sciences and Humanities (MJSSH), 4(7), 168 - 177.

Roslan, Y. (2006). Kesan Kepimpinan Transformasional Pengetua Terhadap Keupayaan Kepimpinan Guru di Dua Buah Sekolah di Pulau Pinang. Kuala Lumpur: Universiti Malaya.

Roslizam Hassan, Jamilah Ahmad \& Yusof Boon. (2018). Professional Learning Community in Malaysia. International Journal of Engineering \& Technology, 1(7), 433-443. http://doi.org/10.14419/ijet.v7i3.30.18347.

Saad, K. A., Walsh, B., Mallaburn, A., \& Brundrett, M. (2017). Exploring The Implementation of a Professional Learning Communities in Malaysian's Schools. International Journal of Education, Psychology and Counseling, 2(5), 1-18.

Samruhaizad Samian @ Samion \& Azahan Awang (2017). Pendidikan sebagai komponen kualiti hidup masyarakat pinggir bandar. Asian Journal of Environment, History and Heritage, 1(1), 267-280.

Saravanan Munian \& Shahizan Hasan. (2020). Hubungan Antara Kepimpinan Transformasi Guru Besar dengan Komitmen Kerja dalam kalangan Guru Sekolah Rendah di Daerah Kulim Bandar Baharu, Kedah. Malaysian Journal of Social Sciences and Humanities (MJSSH), 5(6), 136 - 150. doi.org/10.47405/mjssh.v5i6.434.

Siti Nafsiah Ismail, Zuraidah Abdullah \& Abdul Jalil Othman. (2020). Komuniti Pembelajaran Profesional Guru Bahasa Melayu Malaysia. Jurnal Kepimpinan Pendidikan, 7(1).

Selcuk Doğan \& Alyson Adams. (2018). Effect of professional learning communities on teachers and students. reporting updated results and raising questions about research design, School Effectiveness and School Improvement. DOI: 10.1080/09243453.2018.1500921.

Susan Slick (2002). Teachers Are Enthusiastic Participants in a Learning Community. The Clearing House, 75(4), 198-201. DOI: 10.1080/00098650209604931.

Tai, M. K., \& Omar, A. K. (2019). Professional learning communities: A comparison study between Day Secondary School and Fully Residential Secondary School in Malaysia. International Journal of Academic Research in Progressive Education and Development, 8(2), 87-101.

Tay, Y.C., Yap, C.H. \& Wong, S.H. (2016). Kesan Amalan Pelaksanaan Penyeliaan Pengajaran dan Pembelajaran Bahasa Melayu di Sekolah Rendah. Jurnal Penyelidikan IPGK, 13, 42-52.

Teh, K. P (2019). Modelling The Relationship Among Servant Leadership Organizational Citizenship Behaviour And Teacher Commitment. Sultan Idris Education University, Perak Darul Ridzuan, Malaysia. 
Wieczorek, D., \& Lear, J. (2018). Building the "Bridge": Teacher Leadership for Learning and Distributed. International Journal of Teacher Leadership.

Yogesh Kumar Singh. (2006). Fundamental of Research Methodology and Statistic. New Age International Publisher. New Delhi.

Zuraimy Ali, Azizi Abu Bakar \& Mohd Noor Jaafar. (2016). Pengaruh Gaya Kepemimpinan Transformasi Guru Besar Terhadap Komitmen Guru Pendidikan Islam. Journal of Global Business and Social Entrepreneurship (GBSE), 2(4), 125-134. 